\title{
Preface: Special Issue on Wildland Fires
}

\author{
Alistair M. S. Smith ${ }^{1, *(\mathbb{D})}$, James A. Lutz ${ }^{2}$ (D), Chad M. Hoffman ${ }^{3}$, Grant J. Williamson 4 \\ and Andrew T. Hudak 5 (iD) \\ 1 College of Natural Resources, University of Idaho, Moscow, ID 83844, USA \\ 2 S. J. \& Jessie E. Quinney College of Natural Resources, Utah State University, 5230 Old Main Hill, \\ Logan, UT 84322, USA; james.lutz@usu.edu \\ 3 Warner College of Natural Resources, Colorado State University, Fort Collins, CO 80524, USA; \\ C.Hoffman@colostate.edu \\ 4 School of Natural Sciences, University of Tasmania, Private Bag 55, Hobart, TAS 7001, Australia; \\ grant.williamson@utas.edu.au \\ 5 Research Forester, Forestry Sciences Laboratory, 1221 South Main Street, Moscow, ID 83843, USA; \\ ahudak@fs.fed.us \\ * Correspondence: alistair@uidaho.edu; Tel.: +1-208-885-1009
}

Received: 6 April 2018; Accepted: 6 April 2018; Published: 12 April 2018

\section{Introduction}

Wildland fires are a critical Earth-system process that impacts human populations in each settled continent [1,2]. Wildland fires have often been stated as being essential to human life and civilization through the impacts on land clearance, agriculture, and hunting, with fire as a phenomenon serving a key role in the development of agricultural and industrial practices $[3,4]$. Wildland fires facilitate the redistribution of carbon, water, and nutrients, while unburned refugia within burned area perimeters promote the preservation of key species and habitats [5]. Injected into this socioecological fabric of fire as a landscape process are its immediate and cascading consequences on human health [6], impacts on a wide gamut of ecosystem goods and services [7,8], and consequences on large-scale atmospheric chemistry [9]. The cascading consequences of wildland fires have been recognized to have direct and indirect impacts on several downstream processes including erosion, food and fiber systems, and energy production, as well as the co-occurrence of other natural disasters such as mudslides $[3,10]$. To this day, wildland fires are events of social and ecological concern that frequently occupy the news media in their immediate aftermath. The immediate and cascading impacts of wildland fires on human communities was recently brought into sharp focus in northern California, USA, where the 2017 Thomas Fire was soon followed by heavy rains and devastating mudslides; disaster co-occurrences like this are only projected to increase [2,11-13]. Prescribed fires and other stand management approaches are being widely considered as actions to potentially mitigate the severity and impacts of future unplanned fires $[14,15]$.

This Special Issue was established to solicit contributions from a wide array of wildland fire topics. Although only five articles were published [5,8,16-18], this Special Issue helped set the foundation for the formation of a new MDPI journal, Fire [19].

\section{Highlights}

Three of the papers in this Special Issue deal with stand heterogeneity and patches. In [16], the long-term persistence of patches in monsoon rainforests of Western Australia and the role of Aboriginal burning practices in sustaining them were evaluated. In [5], the characteristics surrounding unburned islands and peninsulas were discussed. Finally, in [17], the influence of landscape heterogeneity on fire behavior was explored using a coupled fire-atmosphere three-dimensional physics-based fire model. 
In [16], the outcomes of a large project focused on coupling traditional ecological knowledge (TEK) and Western scientific approaches around ecological research questions of monsoon vine thickets in Western Australia. This study synthesized environmental information, historical datasets, and remote sensing imagery to evaluate the effectiveness of reinstating Aboriginal fire regimes on the current distribution and patch dynamics of the monsoon rainforests. As would be expected, [16] identified that the rainforests would expand into patches when fires occurred with low frequency and cattle were not present. However, [16] noted that in high-frequency fire regimes with cattle present, the rainforest did not produce more patches, but rather the understory would be suppressed through trampling and fine-scale fuel consumption. Vigilante et al. [16] demonstrated that the role of Aboriginal fire is complex in this ecosystem and that these fires change the monsoon fire regime. Vigilante et al. [16] also highlighted the importance of coupling TEK, historical data, environmental data, and remote sensing to provide long-term monitoring of fire impacts on ecosystem structure and function.

In another paper [5], the importance of fire refugia is highlighted. This work by Haire et al. [5] represents one of only a few studies that have taken on the question of characterizing fire refugia and the characteristics of the sites that lead to these important aspects of patches [20]. Haire et al. [5] defined refugia as unburnt island and peninsulas surrounded by burned areas. In addition, they observed that most of the sites identified as refugia persist through at least two fires. The authors highlighted that research is needed to help predict where and under what conditions refugia will occur and provided some recommendations to help start research into those questions [5].

In the work of Parsons et al. [17], the influence of landscape heterogeneity on fire behavior was explored using FIRETEC, a coupled fire-atmosphere three-dimensional physics-based fire model. The authors simulated fire behavior across a series of fuel, forest canopy cover, and forest heterogeneity and demonstrated that fine-scale spatial fuel patterns significantly impact fire behavior, especially under moderate wind scenarios. The authors highlighted that the findings reinforce the contemporary understanding in fire ecology that fuel variability and fire behavior variability are highly correlated and emphasized that fine-scale fuel aggregation will result in increased regeneration and growth heterogeneity, which are critical to forest resilience [17].

In [18], the role of land-use planning to reduce wildfire risk was discussed with reference to two distinct Mediterranean fire regimes, namely southern France and California. Kocher et al. [18] observed that in France, wildfire risk planning is organized at the national level, while in California, no federal oversight is present. This comparison of the western United States with southern Europe is of particular importance given a projected increase in fire impacts on humans in both these Mediterranean systems [2]. Equally, cross-country policy reviews such as this and others [6] serve as an important basis to understand how to tackle the science-policy interface of fire globally.

In [8], issues related to the uncertainty of fire effects on carbon stocks were analyzed. Using landscape-scale data from Yosemite and Sequoia \& Kings Canyon National Parks in California, USA and extensive ground-truthed data sets, the authors still found high levels of uncertainty in carbon stocks and in the effect of fire on those stocks. The paper emphasizes that much more fundamental work needs to be done in fine-scale landscape classification, plant allometry [21,22], and fire effects [23], especially on large-diameter trees that store the majority of carbon [24], if we are to improve the accuracy of assessments of fire effects on forests.

\section{Future Directions}

Following the development of this Special Issue and a series of subsequent meetings with international fire scientists, operational land use managers, and wildland fire science organizations, it was determined that a significant need existed for a new stand-alone journal. These discussions included participants from three international workshops held between 2014 and 2017 and coordination with a parallel effort from the Global Wildland Fire Network to establish a new vegetation fire journal that could solicit contributions from Europe, Africa, Asia, Oceania, and South America to compliment the preponderance of studies published from North America. The primary reasons that were articulated 
for such a journal focused around a lack of consistent terminology in fire science, the absence of an outlet for technical articles, and the absence of an available forum to share valuable information relating to significant (or extreme, or mega) fire events [25,26], notable fire research endeavors and case studies [27], and land management actions to mitigate the loss of ecosystem goods and services following fires [7]. There was also concern from a wide array of fire science subdisciplines that none of the existing outlets were a good home for their work. In June 2018, this new journal, simply called Fire (mdpi/journals/fire), publishes its first issue. Expanded details on Fire, its mission, and the types of contributions it accepts can be found in [19].

Conflicts of Interest: The authors declare no conflicts of interest.

\section{References}

1. Bowman, D.M.J.S.; Balch, J.K.; Artaxo, P.; Bond, W.J.; Carlson, J.M.; Cochrane, M.A.; D'Antonio, C.M.; Defries, R.S.; Doyle, J.C.; Harrison, S.P.; et al. Fire in the Earth system. Science 2009, 324, 481-484. [CrossRef] [PubMed]

2. Bowman, D.M.J.S.; Williamson, G.J.; Kolden, C.A.; Abatzoglou, J.T.; Cochrane, M.A.; Smith, A.M.S. Human exposure and sensitivity to globally extreme wildfire events. Nat. Ecol. Evol. 2017, 1, 0058. [CrossRef] [PubMed]

3. Smith, A.M.S.; Kolden, C.A.; Paveglio, T.; Cochrane, M.A.; Mortitz, M.A.; Bowman, D.M.J.S.; Hoffman, C.M.; Lutz, J.A.; Queen, L.P.; Hudak, A.T.; et al. The science of firescapes: Achieving fire resilient communities. BioScience 2016, 66, 130-146. [CrossRef] [PubMed]

4. Pyne, S.J. Big Fire; or Introducing the Pyrocene. Fire 2018, 1, 1. [CrossRef]

5. Haire, S.L.; Coop, J.D.; Miller, C. Characterizing spatial neighborhoods of refugia following large fires in Northern New Mexico USA. Land 2017, 6, 19. [CrossRef]

6. Hyde, J.C.; Yedinak, K.M.; Talhelm, A.F.; Smith, A.M.S.; Bowman, D.M.J.S.; Johnson, F.; Lahm, P.; Fitch, M.; Tinkham, W.T. Air quality policy from fire management responses addressing smoke from wildland fires in the United States and Australia. Int. J. Wildland Fire 2017, 26, 347-363.

7. Smith, A.M.S.; Kolden, C.A.; Tinkham, W.T.; Talhelm, A.F.; Marshall, J.D.; Hudak, A.T.; Boschetti, L.; Falkowski, M.J.; Greenberg, J.A.; Anderson, J.W.; et al. Remote sensing the vulnerability of vegetation in natural terrestrial ecosystems. Remote Sens. Environ. 2014, 154, 322-337.

8. Lutz, J.A.; Matchett, J.R.; Tarnay, L.W.; Smith, D.F.; Becker, K.M.L.; Furniss, T.J.; Brooks, M.L. Fire and the distribution and uncertainty of carbon sequestered as aboveground tree biomass in Yosemite and Sequoia \& Kings Canyon National Parks. Land 2017, 6, 10. [CrossRef]

9. Sieler, W.; Crutzen, P.J. Estimates of gross and net fluxes of carbon between the biosphere and atmosphere from biomass burning. Clim. Change 1980, 2, 207-247. [CrossRef]

10. Abatzoglou, J.T.; Kolden, C.A.; DiMento, J.F.C.; Doughman, P.; Nespor, S. Climate-change effects, adaptation, and mitigation. In Climate Change: What It Means for Us, Our Children, and Our Grandchildren; DiMento, J.F.C., Doughman, P., Eds.; MIT Press: Cambridge, MA, USA, 2014; pp. 53-104.

11. Nagy, R.C.; Fusco, E.; Bradley, B.; Abatzoglou, J.T.; Balch, J. Human-related ignitions increase the number of large wildfires across U.S. ecoregions. Fire 2018, 1, 4. [CrossRef]

12. Barbero, R.; Abatzoglou, J.T.; Larkin, N.K.; Kolden, C.A.; Stocks, B.J. Climate change presents increased potential for very large fire in the contiguous United States. Int. J. Wildland Fire 2015, 24, 892-899. [CrossRef]

13. Abatzoglou, J.T.; Kolden, C.A.; Williams, A.P.; Lutz, J.A.; Smith, A.M.S. Climatic influences on inter-annual variability in regional burn severity across western US forests. Int. J. Wildland Fire 2017, 26, 269-275. [CrossRef]

14. Hudak, A.T.; Rickert, I.; Morgan, P.; Strand, E.K.; Lewis, S.A.; Robichaud, P.R.; Hoffman, C.M.; Holden, Z.A. Review of Fuel Treatment Effectiveness in Forests and Rangelands and a Case Study from the 2007 Megafires in Central, Idaho, USA; Gen. Tech. Rep. RMRS-GTR-252; U.S. Department of Agriculture, Forest Service, Rocky Mountain Research Station: Fort Collins, CO, USA, 2011; p. 60.

15. Hessburg, P.F.; Spies, T.A.; Perry, D.A.; Skinner, C.N.; Taylor, A.H.; Brown, P.M.; Stephens, S.L.; Larson, A.J.; Churchill, D.J.; Povak, N.A.; et al. Tamm Review: Management of mixed-severity fire regime forests in Oregon, Washington, and Northern California. For. Ecol. Manag. 2016, 366, 221-250. [CrossRef] 
16. Vigilante, T.; Ondei, S.; Gonnack, C.; Williams, D.; Young, P.; Bowman, D.M.J.S. Collaborative research on the ecology and management of the 'Wulo' Monsoon rainforest in Wunambl Gaambera County, North Kimberley, Australia. Land 2017, 6, 68. [CrossRef]

17. Parsons, R.A.; Linn, R.R.; Pimont, F.; Hoffman, C.M.; Sauer, J.; Winterkamp, J.; Sieg, C.H.; Jolly, W.M. Numerical investigation of aggregated fuel spatial pattern impacts on fire behavior. Land 2017, 6, 43. [CrossRef]

18. Kocher, S.D.; Butsic, V. Governance of land use planning to reduce fire risk to homes in Mediterranean France and California. Land 2017, 6, 24. [CrossRef]

19. Smith, A.M.S.; Goldammer, J.G.; Bowman, D.M.J.S. Introducing Fire: A transdisciplinary journal to advance understanding and management of landscape fires from local to global scales in the past, present, and future. Fire 2018, 1, 2. [CrossRef]

20. Kolden, C.A.; Bleeker, T.M.; Smith, A.M.S.; Puulos, H.M.; Camp, A.E. Fire effects on historical refugia in contemporary wildfires. Forests 2017, 8, 400. [CrossRef]

21. Lutz, J.A.; Schwindt, K.A.; Furniss, T.J.; Freund, J.A.; Swanson, M.E.; Hogan, K.I.; Kenagy, G.E.; Larson, A.J. Community composition and allometry of Leucothoe davisiae, Cornus sericea, and Chrysolepis sempervirens. Can. J. For. Res. 2014, 44, 677-683. [CrossRef]

22. Lutz, J.A.; Furniss, T.J.; Germain, S.J.; Becker, K.M.L.; Blomdahl, E.M.; Jeronimo, S.M.A.; Cansler, C.A.; Freund, J.A.; Swanson, M.E.; Larson, A.J. Shrub communities, spatial patterns, and shrub-mediated tree mortality following reintroduced fire in Yosemite National Park, California, USA. Fire Ecol. 2017, 13, 104-126. [CrossRef]

23. Lutz, J.A.; Larson, A.J.; Swanson, M.E. Advancing fire science with large forest plots and a long-term multidisciplinary approach. Fire 2018, 1, 5. [CrossRef]

24. Lutz, J.A.; Furniss, T.J.; Johnson, D.J.; Davies, S.J.; Allen, D.; Alonso, A.; Anderson-Teixeira, K.; Andrade, A.; Baltzer, J.; Becker, K.M.L.; et al. Global importance of large-diameter trees. Glob. Ecol. Biogeogr. 2018. [CrossRef]

25. Tedim, F.; Leone, V.; Amraoui, M.; Bouillon, C.; Coughlan, M.R.; Delogu, G.M.; Fernandes, P.M.; Ferreira, C.; McCaffrey, S.; McGee, T.K.; et al. Defining extreme wildfire events: difficulties, challenges, and impacts. Fire 2018, 1, 9. [CrossRef]

26. Lannom, K.O.; Tinkham, W.T.; Smith, A.M.S.; Abatzoglou, J.T.; Newingham, B.A.; Hall, T.E.; Morgan, P.; Strand, E.K.; Paveglio, T.B.; Anderson, J.W.; Sparks, A.M. Defining extreme wildland fires using geospatial data and ancillary metrics. Int. J. Wildland Fire 2014, 23, 322-377. [CrossRef]

27. Hudak, A.T.; Freeborn, P.H.; Lewis, S.A.; Hood, S.M.; Smith, H.Y.; Hardy, C.C.; Kremens, R.J.; Butler, B.W.; Teske, C.; Tissell, R.G.; Queen, L.P.; Nordgren, B.L.; et al. The Cooney Ridge Fire Experiment: An Early Operation to Relate Pre-, Active, and Post-Fire Field and Remotely Sensed Measurements. Fire 2018, 1, 10. [CrossRef]

(C) 2018 by the authors. Licensee MDPI, Basel, Switzerland. This article is an open access article distributed under the terms and conditions of the Creative Commons Attribution (CC BY) license (http://creativecommons.org/licenses/by/4.0/). 